\title{
Хірургічне лікування хордоми крижів
}

\author{
М. М. Лешко ${ }^{1}$, Є. І. Слинько ${ }^{2}$, Т. А. Малишева ${ }^{2}$ \\ ${ }^{1}$ Олександрівська клінічна лікарня, м. Київ, \\ ${ }^{2}$ Інститут нейрохірургії імені А. П. Ромоданова НАМН України, м. Київ

\section{Surgical treatment of lumbar chordoma}

\author{
M. M. Leshko ${ }^{1}$, E. I. Slynko ${ }^{2}$, T. A. Malysheva ${ }^{2}$
}

${ }^{1}$ Olexandrivskyi Clinical Hospital, Kyiv,

${ }^{2}$ Romodanov Institute of Neurosurgery, Kyiv

\section{Реферат}

Мета. Аналіз хірургічної техніки, результатів хірургічного та комбінованого лікування хордоми крижів.

Матеріали і методи. У 28 хворих з хордомами крижів проаналізовано симптоми захворювання та їх динаміку, цінність методів нейровізуалізації, особливості патогістологічної картини, хірургічну техніку, ефективність променевої терапії та віддалені результати лікування.

Результати. Серед клінічних проявів хордоми крижів домінував больовий синдром. Середня тривалість анамнезу становила близько одного року. Хірургічну резекцію пухлини через задній доступ виконали 18 хворим, через комбінований - 9 хворим. Видалення пухлин оцінене як радикальне у 21 хворого, часткове - у 7 хворих. У післяопераційному періоді всім хворим проведено курс променевої терапії на лінійному прискорювачі. Протягом 5 років у 26 хворих виник рецидив хордоми. Повторне оперативне втручання виконали 22 хворим.

Висновки. Лікування хордом потребує комплексного підходу. Методом вибору залишається виконання радикального хірургічного втручання, що можливо не у всіх хворих.

ключові слова: хордома; крижі; пухлина; хірургічне лікування; радіотерапія.

\section{Abstract}

Objective. Analysis of surgical procedure, results of surgical and combined treatment of lumbar chordoma.

Materials and methods. In 28 patients, suffering lumbar chordoma, the disease symptoms and their dynamics, value of the neurovisualization method, peculiarities of pathohistological picture, surgical procedure, efficacy of radiation therapy and late results of treatment were analyzed.

Results. Among clinical signs of lumbar chordoma the pain syndrome have dominated. Median duration of anamnesis have constituted approximately one year. Surgical resection of the tumor via posterior approach was done in 18 patients, and via a combined one - in 9 patients. Excision of the tumors was estimated as a radical in 21 patients, and as a partial one - in 7 patients. Postoperatively in all the patients a course of radiation therapy, using linear accelerators, was conducted. Through five years of follow-up in 26 patients recurrence of chordoma have occurred. Reoperations were performed in 22 patients.

Conclusion. Treatment of chordomas needs complex approach. Conduction of radical surgical intervention, what is not possible in all the patients, still constitutes the method of choice.

Keywords: chordoma; sacrum; tumor; surgical treatment; radiotherapy.

Хордома - рідкісна злоякісна пухлина, що утворюється з клітин нотохорду - ембріональної структури, залишки якої розташовані вздовж хребта. У структурі всіх злоякісних новоутворень кісток частка хордом становить $1-4 \%$. Пухлина характеризується поступовим локальним ростом з формуванням капсули та інвазією в прилеглі структури. Наслідком повільного росту є те, що хордоми слабо чутливі до стандартної променевої терапії та хіміотерапії. Тому хірургічна резекція сакральної хордоми єдиним блоком залишається стандартом лікування. Хірургічне видалення досить складне внаслідок близькості нервових і судинних структур [1 - 3].

Мета дослідження: аналіз хірургічної тактики, результатів хірургічного та комбінованого лікування хордоми крижів.

\section{Матеріали і методи дослідження}

Проаналізовано дані 28 хворих з хордомами крижів, що перебували на лікуванні в Інституті нейрохірургії імені А. П. Ромоданова НАМН України у 2000-2018 рр. Неврологічний статус хворих оцінювали за проявами больового синдрому, сегментарних та провідникових чутливих та моторних порушень. Динаміку неврологічної симптоматики оцінювали з використанням стандартизованих бальних шкал оцінки сенсомоторних неврологічних розладів та больового синдрому перед первинним оперативним втручанням та під час виписки зі стаціонару.

Оцінка сенсорних та моторних порушень. Сегментарні та провідникові сенсорні розлади: анестезія - 0 балів, грубе порушення чутливості - 1 бал, помірне зниження чутливості - 2 бали, незначне зниження чутливості - 3 бали, порушень чутливості немає - 4 бали; сегментарні моторні розлади: рухів у міотомі немає - 0 балів, рухи у міотомі $\epsilon$, але їх недостатньо для виконання елементарних завдань - 1 бал, незначне зменшення рухів у міотомі - 2 бали, рухи в міотомі збережені, але сила м'язів знижена - 3 бали, сегментарних моторних порушень немає - 4 бали; провіднико- 
ві моторні розлади: рухів у нижніх кінцівках немає - 0 балів, глибокий парез нижніх кінцівок - 1 бал, парез нижніх кінцівок середнього ступеня - 2 бали, легкий парез нижніх кінцівок - 3 бали, парезу нижніх кінцівок немає - 4 бали.

Оцінка больового синдрому: інтенсивний біль у стані спокою, що потребує постійного прийому наркотичних знеболювальних препаратів - 5 балів, біль у стані спокою, що потребує постійного прийому ненаркотичних знеболювальних препаратів - 4 бали, біль під час повсякденних фізичних навантажень, що потребує прийому ненаркотичних знеболювальних препаратів на вимогу - 3 бали, біль під час повсякденних фізичних навантажень, що не потребує прийому знеболювальних препаратів - 2 бали, біль під час значних фізичних навантажень - 1 бал, болю немає - 0 балів.

Розташування пухлини, ії розміри, особливості компресії крижових корінців та розташування по відношенню до кісткових структур крижів оцінювали за даними комп'ютерної (КТ) та магнітно-резонансної (МРТ) томографії та електронейроміографії.

Дані опрацьовані статистично з використанням прикладних програм Statistica 6.0 та MS Excel 2010. Розподіл кількісних та порядкових показників описаний за допомогою медіани та діапазону значень. Динаміку змін порядкових показників у групах оцінювали за допомогою непараметричного критерію Вілкоксона. Відмінності вважали статистично значущими, якщо величина р була менше 0,05 .

\section{Результати}

Діагностика. Із 28 хворих з хордомами крижів у 27 об'ємний процес мав неспецифічні симптоми - локалізований глибокий біль та корінцевий біль на рівні ура- ження крижів. Масу в крижовій ділянці, що повільно зростала, відмічено у 9 хворих. У 18 хворих спостерігали порушення функції тазових органів у формі розладів сечовипускання та дефекації. У 7 хворих хордоми, що поширювалися в порожнину малого таза, діагностував проктолог під час ректального дослідження. Медіана тривалості симптомів з моменту появи до оперативного втручання - 11 міс (діапазон 3 - 28 міс).

За даними КТ у всіх 28 хворих з хордомами виявлена вогнищева деструкція крижової кістки. МРТ уможливила візуалізувати чіткі межі пухлинного процесу (наявність капсули) та ступінь компресії нервових структур (рис. 1). Кальцифікація і кісткове розростання у 14 хворих візуалізувалися як гіпоінтенсивні ділянки на Т1-зважених та як гіперінтенсивні ділянки на Т2-зважених зображеннях, що посилювалися у разі використання гадолінієвого контрасту. Сканування кісток було проведене 11 хворим. У всіх 11 хворих у ділянці хордоми спостерігали нормальне або знижене поглинання радіоізотопу.

Лікування. Всім 28 хворим виконали хірургічну резекцію пухлини з широкими межами. Через складну анатомічну структуру крижової ділянки в поєднанні з необхідністю резекції капсули пухлини до візуально неушкоджених тканин, обумовленою інфільтративним ростом пухлини, всі оперативні втручання були вкрай складними. Коли пухлина розташовувалась нижче рівня S3 (у 18 хворих), усі резекції виконували через задній доступ. За наявності ураження на рівні S1-S3 (9 хворих) проксимальні резекції виконували через комбіновані передньо-задні доступи. Особливу увагу приділяли збереженню всіх нервових корінців, оскільки їх ушкодження призводить до тяжкої інвалідизації хворих, зокрема до порушення сечовипускання та дефекації, якщо пошкоджено корінці S2-S5.
Puc. 1. МРТ. Хордома крижів.
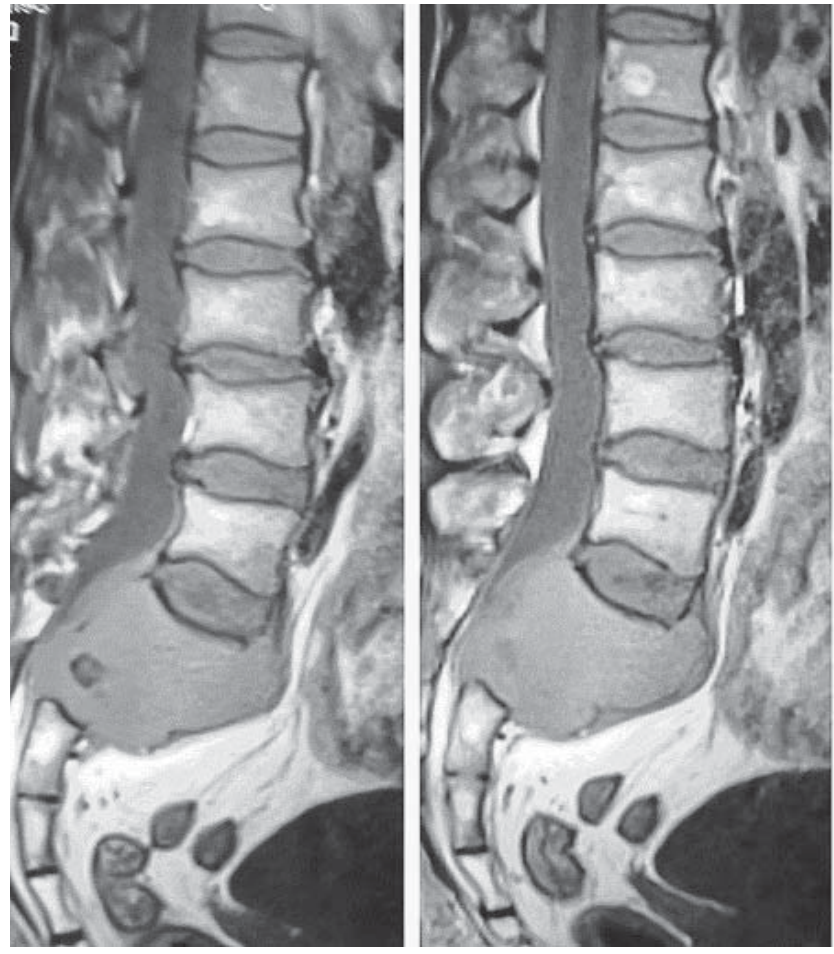

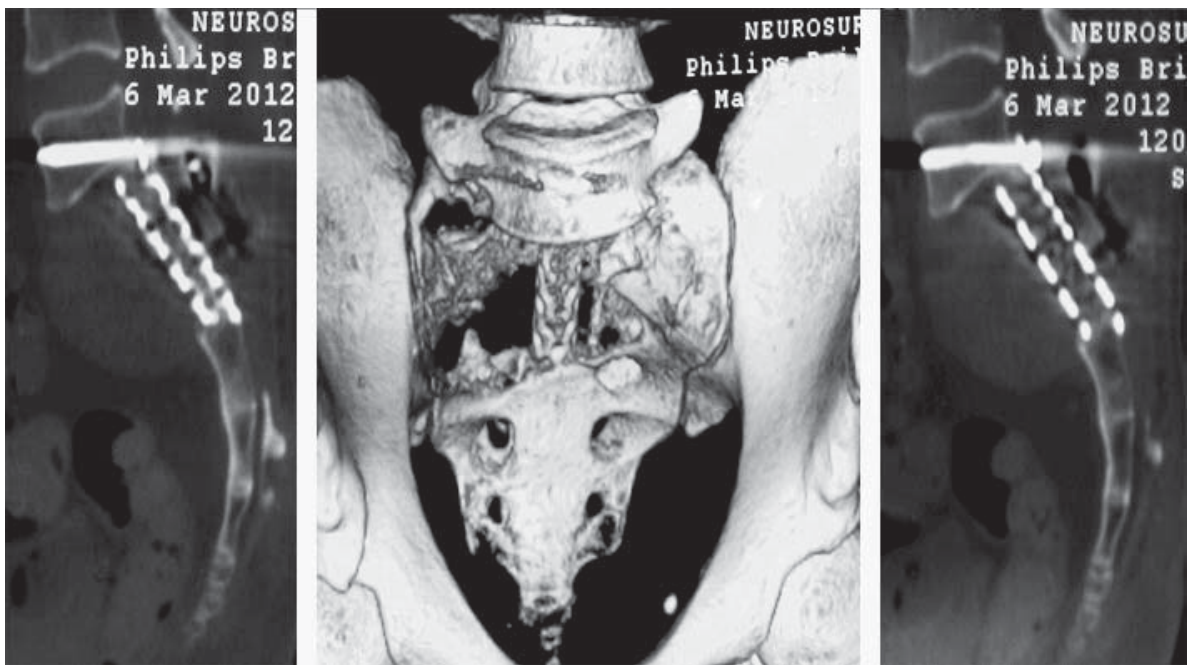

Puc. 2

Спіральна КT.

Стан після видалення хордоми крижів та фіксаціїхребта.

\begin{tabular}{|c|c|c|c|c|}
\hline \multicolumn{5}{|c|}{ Динаміка неврологічної симптоматики в перед- та післяопераційному періодах } \\
\hline \multirow{2}{*}{ Параметр } & \multirow{2}{*}{ Число хворих } & \multicolumn{2}{|c|}{ Оцінка (бали) } & \multirow{2}{*}{$\mathrm{p}$} \\
\hline & & до операції & перед випискою & \\
\hline \multicolumn{5}{|l|}{ Розлади } \\
\hline сегментарні сенсорні розлади & 27 & $2(0-3)$ & $3(0-4)$ & $<0,05$ \\
\hline провідникові сенсорні розлади & 27 & $2(0-3)$ & $3(0-4)$ & $<0,05$ \\
\hline сегментарні моторні розлади & 24 & $2(0-4)$ & $3(0-4)$ & $<0,05$ \\
\hline провідникові моторні розлади & 26 & $3(1-4)$ & $3(2-4)$ & $>0,05$ \\
\hline Больовий синдром & 28 & $3(1-4)$ & $2(0-3)$ & $<0,01$ \\
\hline
\end{tabular}

У 21 хворого виконали радикальне видалення пухлин, у 7 хворих - часткове. Фіксація таза та хребта виконана у 25 хворих (рис. 2).

Динаміку сенсомоторних розладів та больового синдрому в перед- та післяопераційному періодах оцінювали за найтяжчим симптомом у кожній групі; у статистич-

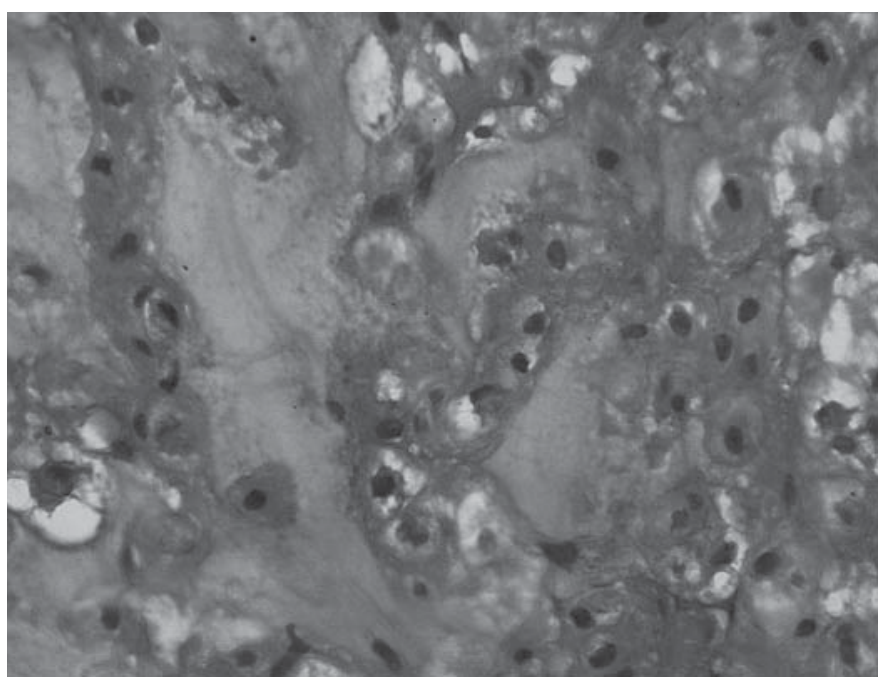

Puc.3.

Гістологічна картина типової хордоми. Альвеолярність за рахунок стромального накопичення базофільної субстанцї̈; клітинний та ядерний поліморфбізм. значна вакуолізаиія цитоплазми; поодинокі мітози. Забарвлення гематоксилін та еозином. Зб. $\times 1000$ ний аналіз включали лише ті спостереження, коли симптоми було оцінено як у передопераційному, так і в післяопераційному періоді (див. таблицю).

Патогістологічна характеристика. За гістологічною будовою виділяють кілька варіантів хордом: ліпоїдна (типова), хондроїдна і недиференційована. Типові хордоми ідентифіковані у 24 хворих, хондроїдні або недиференційовані - у 4. У разі забарвлення зрізів пухлинного вузла гематоксиліном та еозином для хордоми характерні ланцюжки та скупчення великих світлих клітин $з$ круглими ядрами і рясно вакуолізованою еозинофільною цитоплазмою, розділені фіброзними перетинками на часточки. Характерні клітинний та ядерний поліморфізм, поодинокі мітози. Типовій хордомі притаманне формування ланцюжків еозинофільних клітин з сильно вакуолізованою цитоплазмою, схожих на плоди фізалісу (фізаліоїдні клітини). Міжклітинна речовина представлена базофільними гомогенними масами (рис. 3).

Типові хордоми ідентифікували патогістологічно за характерними фізаліоїдними клітинами та імуногістохімічно за наявністю характерних антигенів - S-100, MUC1 (антигену епітеліальної мембрани) і цитокератинів. Хондроїдна хордома експресувала характерні антигени та мала гістологічні особливості, подібні до хондросаркоми та гіалінового хряща, зокрема, саркоматозні ділянки з веретеновими клітинами, типовими для фібросаркоми.

Променева терапія. Усім 28 хворим проведено курс променевої терапії на лінійному прискорювачі. У 18 хворих 
доза не перевищувала 60 Гр, у 10 - становила від 60 до 78 Гр.

Віддалені результати. Нами встановлено декілька прогностичних факторів, пов'язаних з поганою виживаністю: вік, розмір пухлини, передопераційний рівень C-реактивного білка понад 1,0 мг/дл, місце росту пухлини, місцева інвазія в інші тканини, радикальність видалення пухлини, вміст позаклітинного матриксу та гістологічний діагноз (дедиференційована хордома).

Протягом 5 років місцевий рецидив пухлини виник у 26 (93\%) хворих. Повторну резекцію виконано у 22 хворих. Основною причиною відмови від виконання оперативного втручання був незадовільний соматичний стан хворого. Віддалених метастазів хордоми в даному дослідженні не спостерігали.

\section{Обговорення}

Одні автори відносять хордому до хрящових пухлин, інші - до змішаних $[3,4]$. Хордому діагностували у 5 - 6\% хворих з пухлинами хребта переважно старше 40 років, хоча описані спостереження хордоми й у дітей. Значно частіше захворювання виникає у чоловіків. Хордома локалізується переважно у крижово-куприковому відділі (50\%), рідше - в області основи черепа (35\%) та між тілами хребців (15\%), переважно у шийному відділі [5, 6]. 3 огляду на часту локалізацію в крижово-куприковому відділі, утворення досить рано проявляеться порушеннями дефекації, а під час ректального дослідження пальпують пресакральні маси. Провідним рентгенологічним симптомом хордоми є деструкція кісткової структури [6, 7]. Практично всі дослідники сходяться на думці, що найкращі результати має радикальне видалення пухлини єдиним блоком у межах здорових тканин [7]. Оскільки хордома належить до радіорезистентних пухлин, опромінення використовують як паліативне лікування у разі виявлення неоперабельної пухлини або у разі продовженого росту, що спостерігають у 20 - 30\% хворих. Довготривала виживаність пацієнтів з хордомами не перевищує 50\% [4, 8].

\section{Висновки}

1. Лікування хордом має бути комплексним. Методом вибору залишається виконання радикального хірургічного втручання, що, однак, можливо не у всіх хворих.

2. У разі успішного радикального видалення пухлини проведення променевої терапії у післяопераційному періоді недоцільне, необхідне лише спостереження за хворим.

3. У разі виникнення рецидиву або нерадикального видалення пухлини проводять опромінення, в тому числі повторними циклами. Якщо отримана доза унеможливлюе додаткове опромінення, виконують повторне хірургічне втручання, яке, звичайно, не є радикальним, його основна мета - декомпресія нервових структур.

\section{Підтвердження}

Фінансування. Під час проведення дослідження додаткове фінансування не залучали.
Інформація про внесок кожного учасника. Лешко М. М. - концепція і дизайн дослідження, підбір та опрацювання матеріалів, аналіз отриманих даних, написання тексту; Слинько Є. I. - концепція і дизайн дослідження, підбір та опрацювання матеріалів, написання тексту; Малишева Т. А. - підбір та опрацювання матеріалів, написання тексту.

Всі автори прочитали і схвалили остаточний варіант рукопису.

Інформація про конфлікт інтересів. Автори не отримували фінансування на проведення даного дослідження, не є співробітниками та не виконували дослідження на користь виробників систем остеосинтезу, хірургічного інструментарію та обладнання, що використовувалися в ході дослідження.

Згода на публікацію. Всі автори дали згоду на публікацію цього рукопису.

\section{References}

1. Konakondla S, Albers JA, Li X, Barber SM, Nakhla J, Houghton CE, et al. Maximizing Sacral Chordoma Resection by Precise 3-D Tumor Modeling in the OR using Intra-Operative CT Registration with PreOperative MRI Fusion and Intra-Operative Neuronavigation: A Case Series. World Neurosurg. 2019 Feb 18. pii: S1878-8750(19)30376-6. doi: 10.1016/j.wneu.2019.01.257.

2. Houdek MT, Rose PS, Hevesi M, Schwab JH, Griffin AM, Healey JH, et al. Low dose radiotherapy is associated with local complications but not disease control in sacral chordoma. J Surg Oncol. 2019 Feb 7. doi: $10.1002 /$ jso. 25399 .

3. Kashlan ON, Monson DK, Refai D. The Use of Anterior Lumbosacral Interbody Fusion in Spinopelvic Stabilization After High Partial Sacrectomy. Oper Neurosurg (Hagerstown). 2019 Jan 9. doi: 10.1093/ons/opy377.

4. Yang Y, Li Y, Liu W, Xu H, Niu X. The clinical outcome of recurrent sacral chordoma with further surgical treatment. Medicine (Baltimore). 2018 Dec;97(52):e13730. doi: 10.1097/MD.0000000000013730.

5. Zuckerman SL, Amini B, Lee SH, Rao G, Tatsui CE, Rhines LD. Predictive Value of Preoperative Magnetic Resonance Imaging Findings for Survival and Local Recurrence in Patients Undergoing En Bloc Resection of Sacral Chordomas. Neurosurgery. 2018 Dec 12. doi: 10.1093/ neuros/nyy578.

6. Dea N, Fisher CG, Reynolds JJ, Schwab JH, Rhines LD, Gokaslan ZL, et al. Current treatment strategy for newly diagnosed chordoma of the mobile spine and sacrum: results of an international survey. J Neurosurg Spine. 2019 Jan;30(1):119-25. doi: 10.3171/2018.6.SPINE18362.

7. van Wulfften Palthe ODR, Tromp I, Ferreira A, Fiore A, Bramer JAM, van Dijk NC, et al. Sacral chordoma: a clinical review of 101 cases with 30-year experience in a single institution. Spine J. 2018 Nov 14. doi: 10.1016/j.spinee.2018.11.002.

8. Liang WS, Dardis C, Helland A, Sekar S, Adkins J, Cuyugan L, et al. Identification of therapeutic targets in chordoma through comprehensive genomic and transcriptomic analyses. Cold Spring Harb Mol Case Stud. 2018 Dec;4(6):a003418. doi: 10.1101/mcs.a003418. 